\title{
GROWTH OF BACTERIA ON THE SURFACE OF ANION-EXCHANGE RESIN
}

\section{EXPERIMENT WITH BATCH CULTURE}

\author{
REIKO HATTORI, TSUTOMU HATTORI, AND \\ CHOSEKI FURUSAKA \\ Institute for Agricultural Research, Tohoku University, Sendai
}

(Received May 8, 1972)

\begin{abstract}
Bacterial cells adsorbed on an anion-exchange resin, Dowex 1, were incubated in a growth medium. Cell concentration in the liquid part of culture increased gradually at first (first step) and then rapidly (second step). With an incomplete medium or a medium which contains chloramphenicol, secondary rapid increase of the cells was not observed. The rate of secondary increase was much greater than the specific growth rate of free cells. These observations show that the first step is attributable to desorption of adsorbed cells from the resin without growth, while the second step is to detachment of adsorbed cells through growth and the rate of secondary increase reflects the growth rate of adsorbed cells.

As the initial density of adsorbed cells increased, length of the first step decreased and the minimum length of which was 1 to $2 \mathrm{hr}$. Relationship between the relative growth rate and $\mathrm{pH}$ shows that the optimum $\mathrm{pH}$ for growth of adsorbed cells is about one unit higher than that of free cells. It was observed that resin has many physiological influences not only on adsorbed cells growing on its surface but also on the cells detached from it as a result of growth, the most remarkable influence being shown in the case of enzyme induction.
\end{abstract}

There are many studies in soil microbiology or in marine microbiology which suggest that liquid-solid interface has a significant influence on bacterial growth or activities $(1,2,3)$. Recently, the growth of bacteria on a solid surface was studied mainly from two directions. The one was concerned with "the apparatus effect" in a continuous culture as pointed out by HERBERT et al. (4). LARSEN and DIMMICK (5) showed that bacterial cells attached to the surface of a continuous culture vessel contributed to population density and that, for a kinetic analysis of continuous culture, the growth of attached cells should be taken into consideration. As to the other, HELMSTETTER and COOPER $(6,7)$ suggested, in their studies for obtaining synchronous culture of Escherichia coli B, that the doubling time of cells which grew on 
a filter membrane in a flowing medium might be shorter than that of the cells which grew freely in batch culture.

We have shown that chemical activities of several bacteria adsorbed on an anion-exchange resin, Dowex 1, have many differences compared with those of the cells suspended freely in a liquid medium $(8,9,10)$. In the present work, we studied in a batch system how adsorbed bacteria grow on the surface of the same resin and what kind of an influence the resin has on them.

\section{MATERIALS AND METHODS}

Organisms. Escherichia coli Yamaguchi strain and Pseudomonas aeruginos $a$ were used. The cells of $E$. coli were preincubated in a medium composed of $5.0 \mathrm{~g}$ of glucose or lactose, $2.0 \mathrm{~g}$ of $\left(\mathrm{NH}_{4}\right)_{2} \mathrm{SO}_{4}, 21.25 \mathrm{~g}$ of $\mathrm{Na}_{2} \mathrm{HPO}_{4} \cdot 12 \mathrm{H}_{2} \mathrm{O}$, $5.4 \mathrm{~g}$ of $\mathrm{KH}_{2} \mathrm{PO}_{4}, 0.2 \mathrm{~g}$ of $\mathrm{MgSO}_{4}$ and 1 liter of tap water ( $\mathrm{pH} 7.0$ ), with shaking for $16.5 \mathrm{hr}$ at $30^{\circ}$, harvested by centrifugation, resuspended in deionized water (about $10^{10}$ cells $/ \mathrm{ml}$ except when noted otherwise) and used. The cells of Pseudomonas aeruginosa were obtained similarly as in the case of $E$. coli except that a nutrient broth was used. Unless noted, the cells of the former were used.

Resin. Anion-exchange resin, Dowex 1, 100-200 mesh, in chloride form was used.

Growth medium. In the case of $E$. coli, the same medium as for preincubation was used except that $10.0 \mathrm{~g}$ of sugar and $5.0 \mathrm{~g}$ of $\left(\mathrm{NH}_{4}\right)_{2} \mathrm{SO}_{4}$ were included. To study the effect of $\mathrm{pH}, \mathrm{pH}$ of the medium was adjusted by altering the composition of phosphate salts. In the case of $P s$. aeruginosa, nutrient broth was used as a growth medium.

Preparation and incubation of adsorbed cells. One milliliter of the cell suspension was added to $1.5 \mathrm{~g}$ of the resin. After $10 \mathrm{~min}$, the resin was washed about 10 times by decantation with growth medium to remove nonadsorbed cells and used as resin-adsorbed cells. The number of adsorbed cells was estimated as previously reported $(8)$. The resin with adsorbed cells was resuspended in $20 \mathrm{ml}$ of growth medium and incubated at $30^{\circ}$. An aliquot of $20 \mathrm{ml}$ of the last washing of the resin which contained a small number of free cells was similarly incubated as a control. Turbidity of the liquid part of the culture was followed and turbidity values were converted to dry weight of bacteria per unit volume of medium. When needed, the number of viable cells in the liquid part of culture was estimated by the plating method.

Preparation of detached cells. After the adsorbed cells were incubated in a growth medium for several hours, the cells which increased in the liquid part of culture were collected by decantation, washed by centrifugation, and used as the detached cells (see text).

Preparation of desorbed cells. One milliliter of cell suspension was added 
to $1.5 \mathrm{~g}$ of the resin and, after $10 \mathrm{~min}$, the resin was washed several times with deionized water instead of growth medium. Then the resin was shaken vigorously by hand with $1.0 \% \mathrm{NaCl}$ solution. The cells washed out by this procedure were collected by centrifugation, washed, resuspended in deionized water and used as desorbed cells.

Measurement of respiratory activity. Oxygen uptake was measured by the manometric technique as previously reported $(8)$.

Determination of nucleic acids. Nucleic acids in the cells were extracted with hot trichloroacetic acid. The content of RNA or DNA was determined by the orcinol or diphenylamine reaction, respectively.

\section{RESULTS AND DISCUSSION}

Increase of cells in the liquid part of culture during incubation of adsorbed cells

In studying bacterial growth at a liquid-solid interface, there is the difficulty of how to distinguish the cells which grow on an interface from those which grow freely in the liquid part of culture.

The resin, Dowex 1, used in the present experiment has been found to

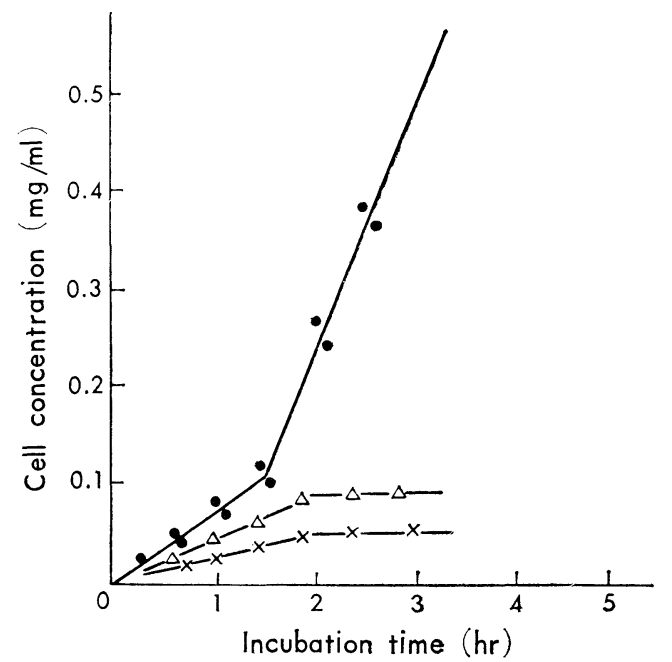

Fig. 1. Increase of cell concentration in the liquid part of culture during incubation of adsorbed cells.

The resin $(1.5 \mathrm{~g})$ with adsorbed cells was incubated at $30^{\circ}$, in $20 \mathrm{ml}$ of medium.

- - Growth medium with lactose as a carbon source.

$\times-\times$, Growth medium with chloramphenicol $(50 \mu \mathrm{g} / \mathrm{ml})$.

$\triangle-\triangle$, Growth medium without carbon or nitrogen sources. 


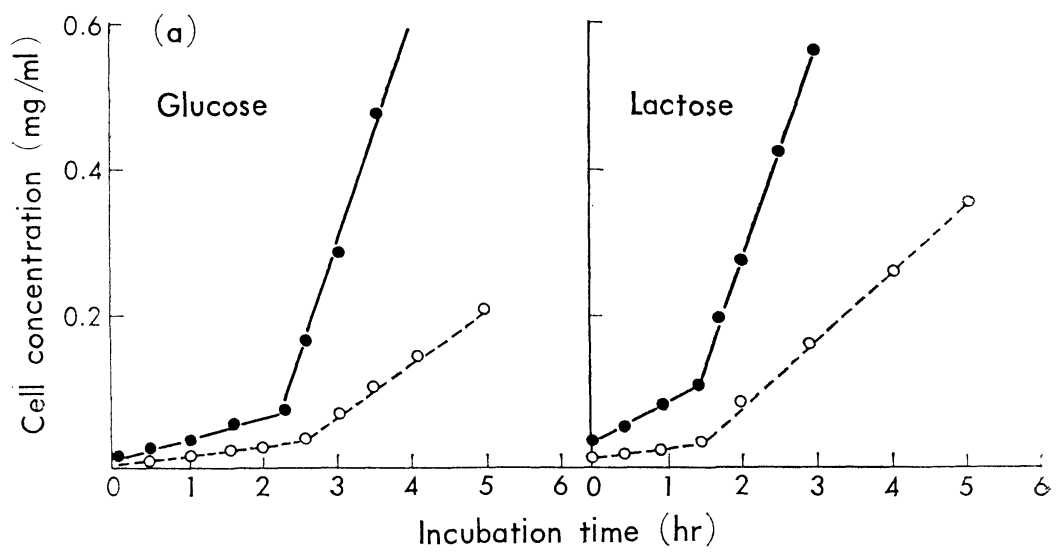

(b)

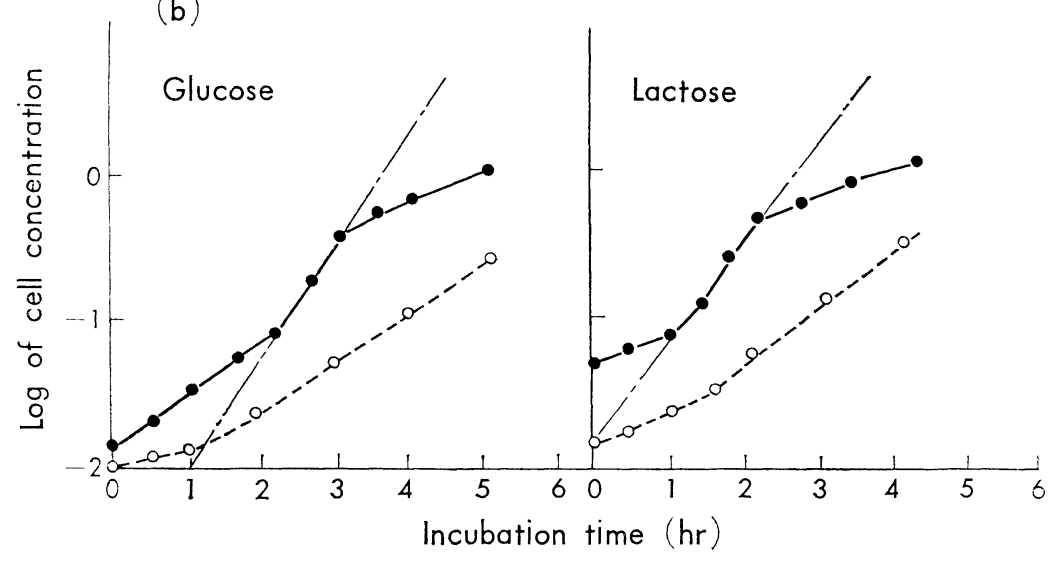

Fig. 2. Rate of increase of cell concentration in the liquid part of culture during incubation of adsorbed cells compared with growth rate of free cells.

(a) Increase of cell concentration during incubation.

(b) Increase of cell concentration plotted on logarithmic scale.

Adsorbed cells in $20 \mathrm{ml}$ of growth medium or $20 \mathrm{ml}$ of the last washing of the resin which contained small number of free cells was incubated at $30^{\circ}$. Growth medium contained glucose or lactose as the sole carbon source.

- - - adsorbed cells; $\bigcirc-0$, free cells.

be an excellent material regarding this problem because it adsorbs bacteria tightly, at least in a resting state. By washing the resin with adsorbed cells repeatedly before incubation, the number of free cells which initially coexist with adsorbed cells can be made as small as possible and thus free cells do not intensely disturb the population from the resin surface, at least in a first few hours of incubation. 


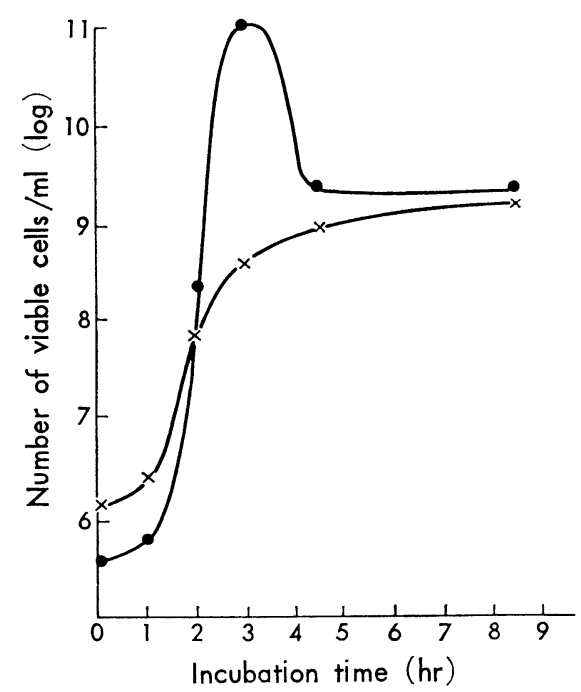

Fig. 3. Increase in number of viable cells in the liquid part of culture during incubation of adsorbed cells.

Adsorbed cells were incubated in growth medium with glucose as a sole carbon source: - $-8 \mathrm{~g}$ of resin with adsorbed cells; $x-x, 2 \mathrm{~g}$ of resin with adsorbed cells. In this experiment $100 \mathrm{ml}$ of medium was used. The initial number of adsorbed cells was about $10^{10}$ cells $\mathrm{g}$ resin.

When adsorbed cells were incubated in the growth medium, cell concentration in the liquid part of culture increased gradually at first (first step) and then very rapidly (second step). In a medium without carbon or nitrogen source or a medium with chloramphenicol $(50 \mu \mathrm{g} / \mathrm{ml})$, cell concentration also increased gradually but then the increase stopped and a rapid increase as in a complete medium was not odserved (Fig. 1). The maximum rate of increase of cell concentration in the second step is much greater than the specific growth rate of free cells (Fig. 2a), though curves with adsorbed cells plotted on a logarithmic scale against time are rather complex (Fig. $2 \mathrm{~b}$ ). The number of viable cells in the liquid part of culture sometimes exceeded the initial number of adsorbed cells by 10-to 100-fold within a few hours after incubation of adsorbed cells (Fig. 3).

From these observations, the first step of cell increase seems to result from desorption of adsorbed cells without growth from the surface of resin (desorption), although some physiological changes might be concerned with the process because the rate of desorption depends on the composition of a medium (Fig. 1). On the other hand, the second step of cell increase is attributable mainly to the detachment of adsorbed cells through growth on the 

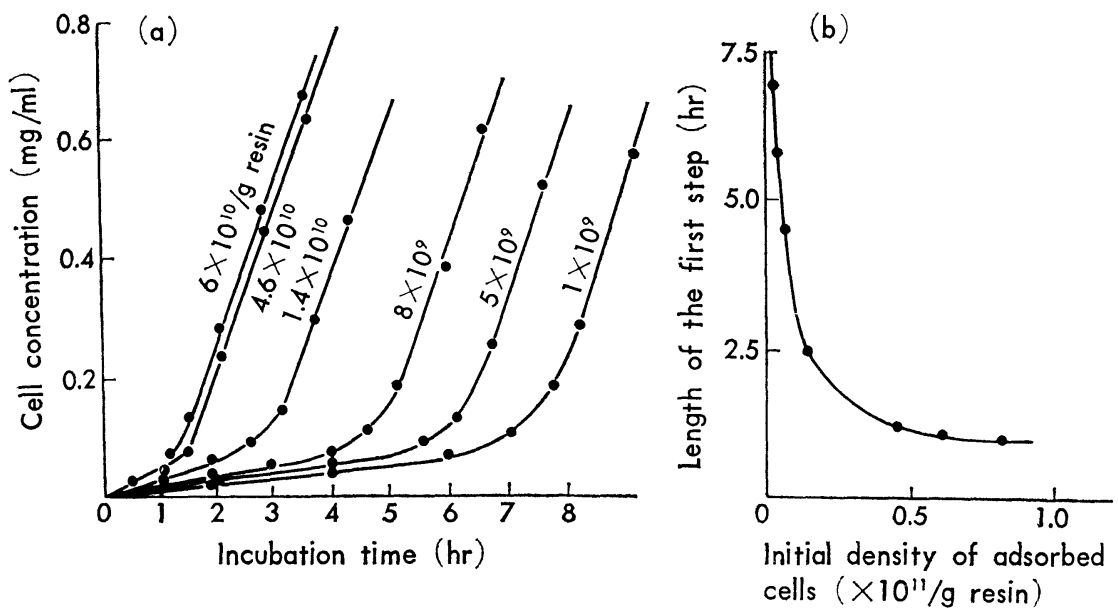

Fig. 4. Relation between the duration of the first step and initial density of adsorbed cells.

One milliliter of cell suspension of varied concentration was added to $1.5 \mathrm{~g}$ of the resin and the initial number of adsorbed cells as shown in the figure was estimated as in the previous report (9). Adsorbed cells were incubated at $30^{\circ}$ in the growth medium with glucose as the carbon source. The increase of cell concentration in the liquid part of culture was followed (a) and duration of the first step was plotted against the initial density of adsorbed cells (b).

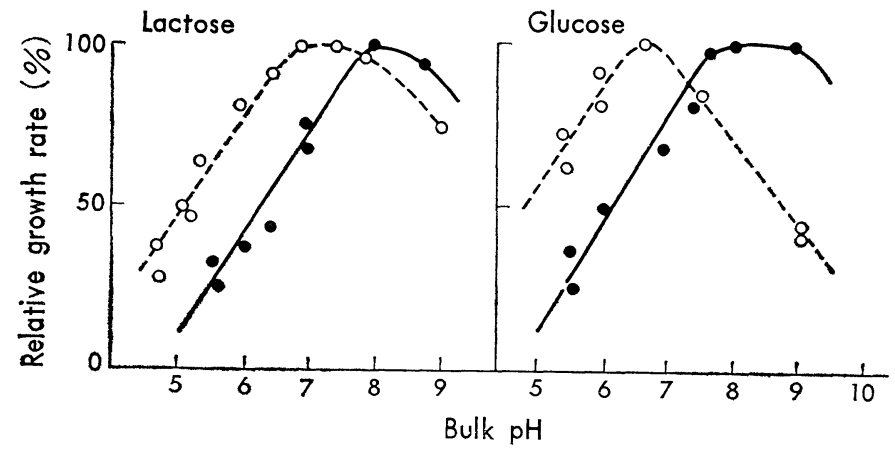

Fig. 5. Effect of $\mathrm{pH}$ on the growth rate of adsorbed cells in medium with glucose or lactose as sole carbon source.

Growth rate was obtained from the slope of the second step in each medium of various $\mathrm{pH}$. The maximum rate was taken arbitrarily as 100 .

-- Adsorbed cells; $\bigcirc--\mathrm{C}$, Free cells. 


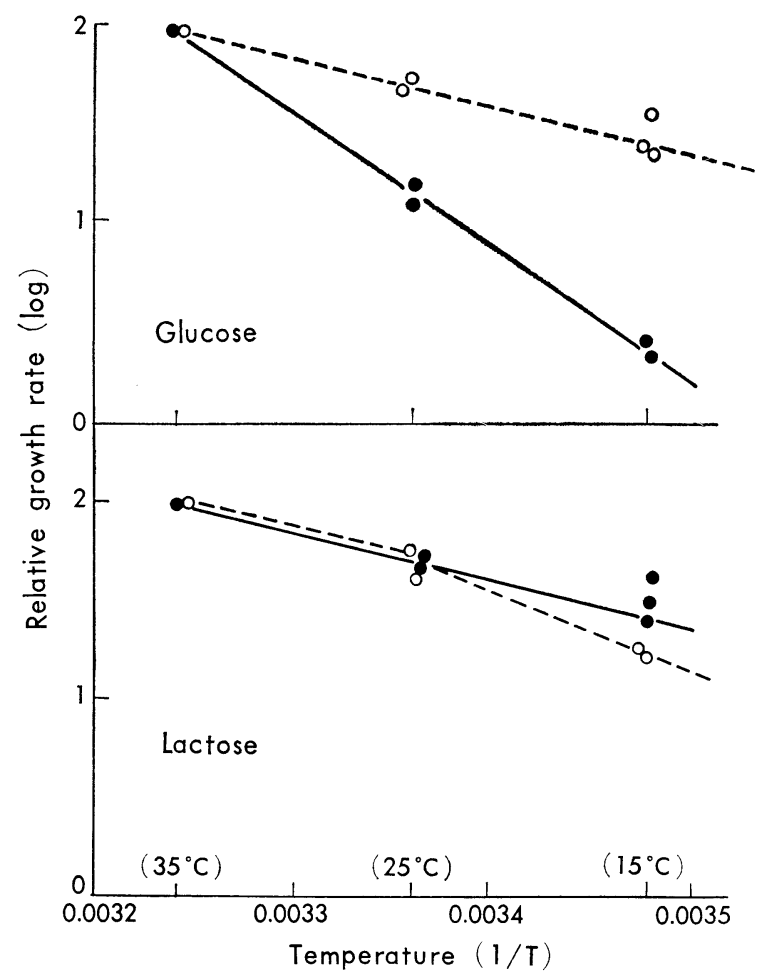

Fig. 6. Effect of temperature on the growth rate of adsorbed cells in medium with glucose or lactose as a sole carbon source.

Growth rate was obtained from the slope of the second step, at each temperature. The growth rate at $35^{\circ}$ was taken arbitrarily as 100 .

-- - Adsorbed cells; $\bigcirc-\bigcirc$, Free cells.

surface of resin (detachment) and the rate of increase reflects the growth rate of adsorbed cells.

As the initial number of adsorbed cells per unit surface of the resin increased, duration of the first step decreased (Figs. 4a and b) and the minimum length of duration was between 1 and $2 \mathrm{hr}$, but the rate of cell increase in the second step was independent of initial density of adsorbed cells. It seems that a certain threshold density is necessary for adsorbed cells to divide and to detach from the resin rapidly. That is, when the number of adsorbed cells per unit surface of resin is small, the cells divide solely on the surface of resin and, after the number has increased to a certain level as the result of division, they grow rapidly and detach into the medium. Duration of the first step probably reflects the lag time for growth and also the time necessary for adsorbed cells to divide to a threshold density. 


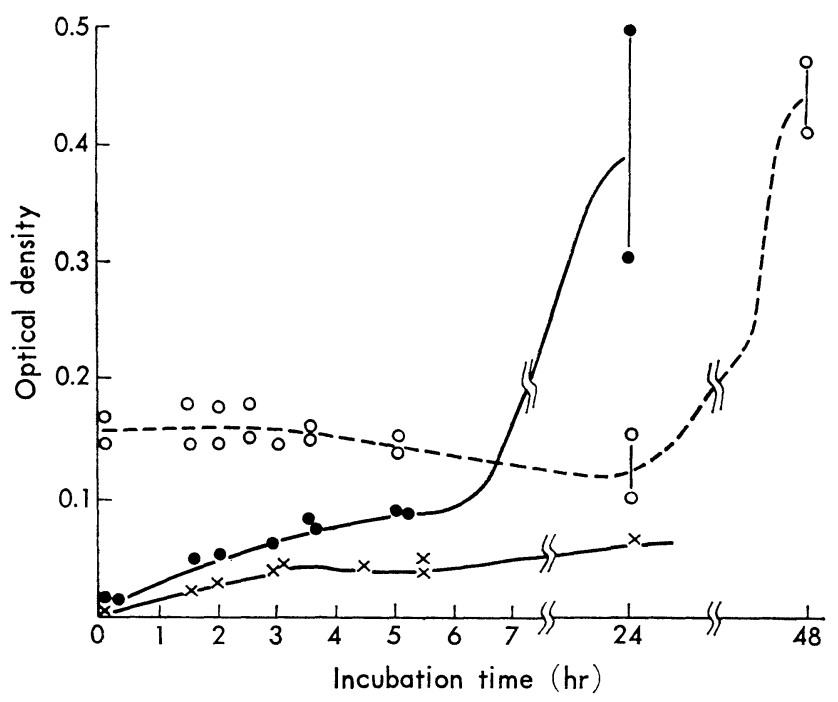

Fig. 7. Adaptive growth of adsorbed cells and free cells.

Cells of $E$. coli precultured in a medium with glucose as the sole carbon source were washed with deionized water, adsorbed on $1.5 \mathrm{~g}$ of resin, and incubated in $20 \mathrm{ml}$ of growth medium with sodium citrate as the sole carbon source or in a medium from which nitrogen source was omitted. Free cells which had been precultured and washed similarly were incubated in the same growth medium as a control. Turbidity of the liquid part of culture or of cell suspension was followed.

- - Adsorbed cells in the growth medium;

$x-x$, Adsorbed cells in the medium without nitrogen source;

$0--\bigcirc$, Free cells in the growth medium.

\section{Effect of $p H$ on the growth rate of adsorbed cells}

As mentioned above, the rate of cell increase in the second step may reflect the growth rate of adsorbed cells, and the growth rate was studied in relation to $\mathrm{pH}$ of media. The $\mathrm{pH}$ value for the optimum growth of adsorbed cells was about one unit higher than that of free cells (Fig. 5), suggesting that a cationic layer on the surface of the resin influences bacterial growth as in the case of chemical activities $(8,9,10)$.

\section{Effect of temperature on the growth rate of adsorbed cells}

Figure 6 shows the effect of temperature on the growth rate of adsorbed cells. In a medium with lactose as the sole carbon source, the effect of temperature on adsorbed cells was nearly the same as that on free cells, but not in a medium with glucose. 


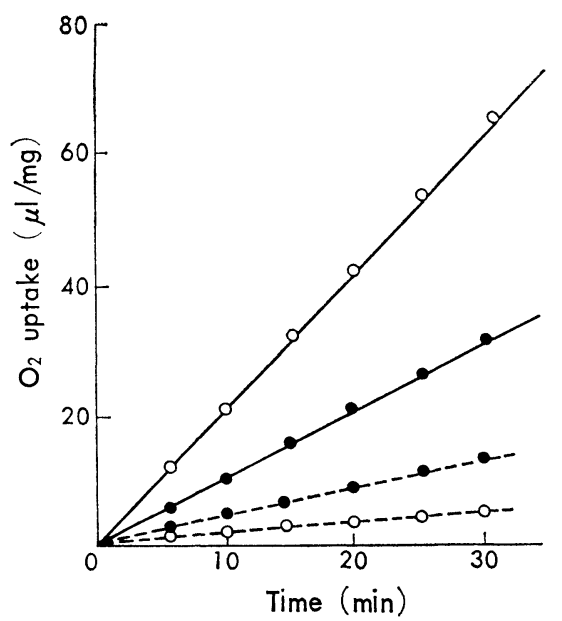

Fig. 8. Oxygen uptake by detached or freely grown cells.

Oxygen uptake in the presence of glucose: - - , by detached cells; $\mathrm{O}-\mathrm{O}$, by freely grown cells.

Endogenous respiration: -- , by detached cells; $\bigcirc-\bigcirc$, by freely grown cells.

After $2.5 \mathrm{hr}$ of incubation of adsorbed cells in a medium with glucose as the carbon source, detached cells were prepared and their oxygen uptake was measured. Oxygen uptake of freely grown cells incubated for $2.5 \mathrm{hr}$ in the same medium was used as a control.

\section{Adaptive growth of adsorbed cells}

Previous reports have shown that a lag time for enzyme induction with adsorbed cells decreases remarkably compared with that with free cells ( 8 , 9, 10).

In the present experiment, adaptive growth was compared in adsorbed and free cells which had been preincubated in a medium with glucose as a sole carbon source and then incubated in a medium with sodium citrate as a sole carbon source. Although appreciable growth was not observed for $48 \mathrm{hr}$ with free cells, a remarkable increase of cells in the liquid part of culture was observed after $24 \mathrm{hr}$ with adsorbed cells (Fig. 7). Increase of the cells in the latter case might not be the result of desorption, because, in the medium without a nitrogen source, such a remarkable cell increase was not observed. This result means that the resin influences adaptive growth of adsorbed cells as in the induction of chemical activities.

\section{Chemical activities of detached cells}

Examinations were made on whether the influence of resin on the physiology of bacteria would also be observed in the case of detached cells. 


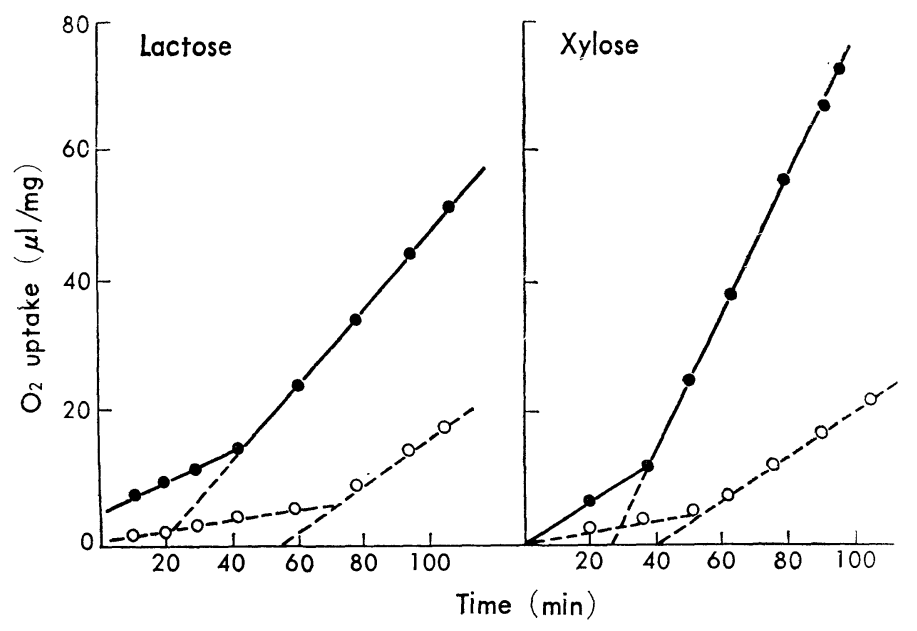

Fig. 9. Lag time for enzyme induction with detached cells compared with that with freely grown cells.

After $2.5 \mathrm{hr}$ of incubation in a growth medium with glucose as a sole carbon source, detached and freely grown cells were prepared and the lag time for enzyme induction was estimated, when lactose or xylose was used as a substrate.

-- ๑, Detached cells; $\bigcirc-\bigcirc$, Freely grown cells.

After $2.5 \mathrm{hr}$ of incubation of adsorbed cells, detached cells were prepared and their chemical activity was examined, with activities of free cells incubated for the same period as a control (freely grown cells). As shown in Fig. 8, oxygen uptake in the presence of glucose by detached cells was lower than that by freely grown cells, although, strictly speaking, activities cannot be compared between the former and the latter, since oxidative activity of bacteria varies with growth phase. A similar result was obtained with lactose. On the contrary, it should be noted that the activities of endogenous respiration was always higher in detached cells than in freely grown cells.

Figure 9 shows that the lag time for enzyme induction is shorter in detached cells than in freely grown cells when lactose or xylose was used as a substrate. A similar result was obtained in the case of Ps. aeruginosa with sodium benzoate as a substrate (Fig. 10).

Content of nucleic acids in free cells, desorbed cells, freely grown cells, and detached cells

In the previous report, it was shown that adsorbed cells were deprived of certain substances by the resin, in which oligonucleotides were included (9). We compared the content of nucleic acids between free cells and desorbed cells which were in resting state and that between freely grown cells 


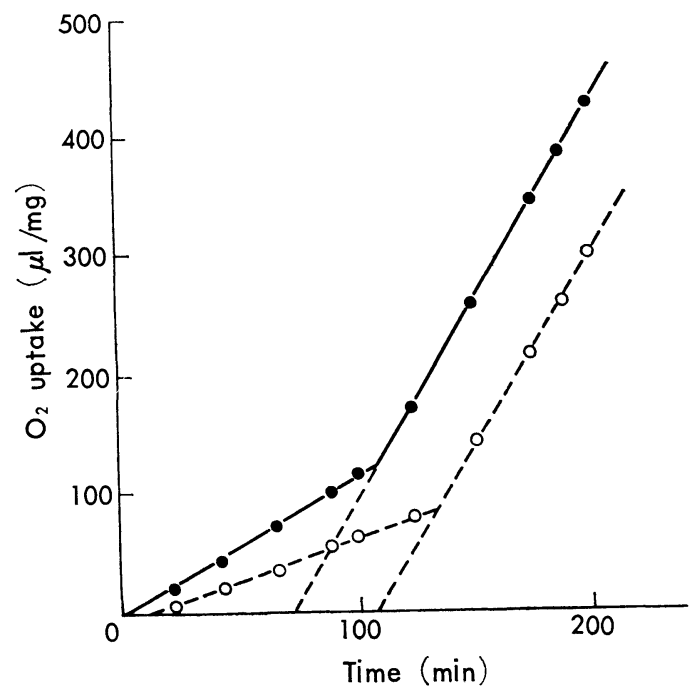

Fig. 10. Lag time for enzyme induction with detached cells and freely grown cells of Ps. aeruginosa.

After $16.5 \mathrm{hr}$ of incubation in the nutrient broth, detached and freely grown cells were prepared and lag time for enzyme induction was estimated when sodium benzoate was used as a substrate.

- - D Detached cells; $\bigcirc-\bigcirc$, Freely grown cells.

Table 1. Content of nucleic acids in free cells and desorbed cells.

\begin{tabular}{lc|c|c}
\hline & & $\begin{array}{c}\text { DNA } \\
(\mu \mathrm{g} / \mathrm{mg} \text { dry weight })\end{array}$ & $\begin{array}{c}\text { RNA } \\
(\mu \mathrm{g} / \mathrm{mg} \text { dry weight })\end{array}$ \\
\hline \multirow{2}{*}{ Free cells } & $(1)$ & 40.3 & 82.5 \\
& $(2)$ & 37.1 & 85.0 \\
Desorbed cells & $(1)$ & 44.8 & 60.0 \\
& $(2)$ & 41.8 & 65.5 \\
\hline
\end{tabular}

and detached cells which were in growing state. Table 1 shows the content of DNA and RNA in free and desorbed cells. The content of DNA in desorbed cells is apparently the same as that in free cells but the content of RNA in the former is considerably lower than that in the latter.

Fig. 11 shows how the content of RNA varies during growth with freely grown and detached cells. The content of RNA in freely grown cells varied significantly in lag phase but the value remains almost at a constant level in the logarithmic phase. The content of RNA in detached cells varies in the 


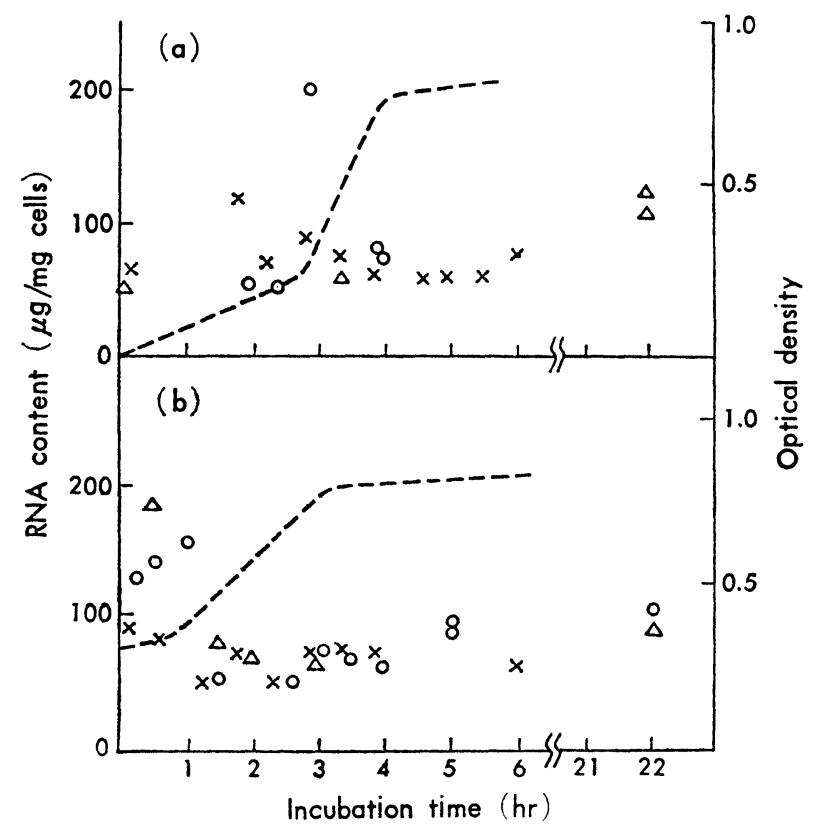

Fig. 11. Variation in the content of RNA during incubation of adsorbed and free cells.

Many samples of adsorbed cells and free cells were incubated simultaneously in a growth medium with glucose as a carbon source. Samples were harvested one by one at each time plotted and detached cells and freely-grown cells were prepared.

$x, \bigcirc$, and $\triangle$ show the values of RNA content in detached cells or those in freely-grown cells estimated in a separate experiment. (a) detached cells (b) freely grown cells.

-.-- shows the increase of cell concentration in the liquid part of culture during incubation of adsorbed cells (a) or the growth curve with freely grown cells (b).

first step but values also remain at a constant level in the second step, the level being nearly the same as that of freely grown cells.

These results show that the resin has some direct effect on the physiological characters of growing cells. It should be noted that some of these effects remain not olny on adsorbed cells but also on detached cells.

Further investigations on how adsorbed cells behave on the surface of the same resin during growth will be described in the next report.

\section{REFERENCES}

1) H.J. Conn and J.E. Conn, Soil Sci., 52, 121 (1941). 
2) H. HeukelekiAN and A. Heller, J. Bacteriol., 40, 547 (1940).

3) C.E. Zobell, J. Bacteriol., 46, 39 (1943).

4) D. Herbert, R. Elsworth, and R.C. Telling, J. Gen. Microbiol., 14, 601 (1956).

5) DON H. LARSEN and R.L. DIMMICK, J. Bacteriol., 88, 1380 (1964).

6) C.E. Helmstetter, J. Mol. Biol., 24, 417 (1967).

7) C.E. Helmstetter and S. Cooper, J. Mol. Biol., 31, 507 (1968).

8) T. Hattori and C. Furusaka, J. Biochem. (Tokyo), 48, 831 (1960).

9) T. Hattori and C. Furusaka, J. Biochem. (Tokyo), 50, 312 (1961).

10) R. HAtToRi and T. HAtToRi, Ecological Rev., 16, 63 (1963). 